\title{
Morphological Characterization of Wild and Cultured Clarias gariepinus (Burchell 1822) Using Principal Component and Cluster Analyses
}

\author{
Folasade A. OLA-OLADIMEJI ${ }^{1 *}$, Michael O. AWODIRAN ${ }^{2}$, Omotayo \\ FAGBUARO $^{1}$, Adetola O. AKOMOLAFE ${ }^{1}$
}

\author{
${ }^{I}$ Ekiti State University, Faculty of Science, Department of Zoology and Environmental Biology, Ado-Ekiti, \\ Nigeria; folasade.majolagbe@eksu.edu.ng (*corresponding author) \\ ${ }^{2}$ Obafemi Awolowo University, Faculty of Science, Department of Zoology, Ile-Ife, Nigeria
}

\begin{abstract}
The study was designed to describe the phenotypic variations in morphometric and meristic characters of Clarias gariepinus between two populations in different towns in Ekiti State, Nigeria. Fish samples were collected from Ero dam (wild population at Ikun Ekiti) and Christeve Aquaculture (cultured population at Iyin Ekiti) using cast net and dragging net. The samples were brought to Zoology Laboratory in Ekiti State University and measurements for morphometrics (24) and meristics (11) of each of the investigated catfish specimen were taken using standard procedures. To test the significance of morphological differences between the wild and cultured populations, all the data on morphometrics and meristics were subjected to student's t-test at 5\% level of significance. Principal Component Analyses and cluster analyses were then employed to analyse the data obtained from the morphological traits using Paleontological Statistics (PAST) software. Significant differences were observed in the means of the morphometric and meristic traits. The multivariate analysis also showed differences between the studied populations. These differences revealed the occurrence of heterogeneity between the two populations. Higher variations and sex related variations were also observed in the wild than in cultured population. The result show the potential for commercial purposes of the population. However, genetic markers can be used in further studies to confirm the phenotypic diversity observed and assess the amount of variation in these populations.
\end{abstract}

Keywords: cast net, dragging net, heterogeneity, student's t-test, traits

\section{Introduction}

Fish is the cheapest source of animal protein eaten by the average Nigerian population, accounting for about $40 \%$ of the total protein intake (Atanda, 2007). In recent years, the culture of species belonging to the Clariidae family is fast gaining global attention in Africa, especially in Nigeria. The species mostly cultured are Clarias gariepinus, Heterobranchus species and their hybrids (Adewolu et al., 2008).

They are widely cultured because of their high market price, fast growth rate and ability to withstand adverse conditions especially low oxygen content (Adewolu and Adeoti, 2010).

Morphometric and meristic characters are widely used to identify fish stocks (Turan et al., 2004) and they remain the simplest, most direct method of species identification. From previous studies, (Creech, 1992; Mamuris et al., 1998; Bronte et al., 1999; Hockaday et al., 2000), it is understood that the analysis of phenotypic variations in morphometric or meristic characters is the most commonly used method to describe fish stocks. It has often been used in discrimination and classification studies by statistical techniques (Agnew, 1988; Avsar, 1994).

Several marker technologies have been employed in fish diversity studies which include morphometrics, isozymes, cytology and recently molecular markers (DNA markers) (Ferguson and Dangamam, 1998) and despite the advent of these techniques which directly examine biochemical or molecular genetic variation, this conventional method (morphometrics) continues to play an important role in stock identification (Swain and Foote, 1999).

Although a number of studies have been carried out on the morphometrics of $C$. gariepinus in many places (Popoola et al. 2014; Fagbuaro et al., 2015) however, no published work has been done on the comparison of $C$. gariepinus between Ero dam (wild population at Ikun Ekiti) and 
429

Christeve Aquaculture (cultured population at Iyin Ekiti) in Ekiti State using the multivariate analysis.

Thus, the present investigation aimed at determining if there is significant morphological heterogeneity or homogeneity between two populations of Clarias gariepinus and the results of such study may provide information on the stocks to be used for breeding purposes.

\section{Materials and Methods}

\section{Collection of fish samples}

A total of sixty (60) Clarias gariepinus specimens were collected from Ero dam at Ikun Ekiti and forty (40) from another pond named Christeve Aquaculture at Iyin-Ekiti. They were collected by cast net and dragging net and transported to Zoology Laboratory in Ekiti State University, Ado-Ekiti for their measurements.

The samples were identified by an expert in fisheries in the Department. The specimen weights were first taken using the weighing balance, before the other morphometric measurements were carried out.

Twenty four (24) morphometric measurements were investigated according to Teugels (1986). These were:

Standard length (SL), Total length (TL), Weight (W), Dorsal fin length (DFL), Anal fin length (AFL), Pectoral fin length (PFL), Spine length (SPL), Head length (HL), Snout length (SNL), Length of occipital fontanelle (OFL), Pre anal distance (PAD), Pre ventral distance (PVD), Pre pectoral distance (PPD), Pre dorsal distance (PDD), Distance between dorsal and caudal fin (DDCF), Distances between occipital process and dorsal fin (DODF), Caudal peduncle depth (CPD), Body depth (BD), Head width (HW), Inter orbital distance (ID), Eye diameter (ED), Width of occipital fontanelle (OFW), Distance between snout and occipital process (DSO) and Mouth length (ML).

Eleven (11) meristic measurements were also investigated. These were:

Number of barbels (nB), Number of Gills (nG), Number of Spine (nS), Number of Gill arch (GA), Number of Gill filament (GF), Number of Gill rakers (GR), Dorsal fin ray (DFR), Anal fin ray (AFR), Pectoral fin ray (PFR), Pelvic fin ray (PVFR), Number of vertebrae column (VC).

\section{Statisticalanalysis}

T-test was carried out to test the significance of morphological differences between the wild and cultured populations at $\mathrm{P}<0.05$.

According to Jordi et al. (2000) size must be considered as a contingent source of variability in morphometrics, since it is associated with individual growth. Hence, the measurements of each of the morphometric traits of each catfish standardized to fish size (SL) followed the protocol of Reist (1985) to remove size-effect as follows: $M n=(M o / S L) \%$, where: $M n$ is the corrected size, $M o$ is the original measurement (total length) and SL is the standard length.

However, the measurements of each of the meristic traits were not standardized.

The data obtained from the morphological traits were then analysed with Principal Component Analyses and cluster analyses. PCA and cluster analyses on morphometric and meristic data were evaluated using Paleontological Statistics (PAST) software (Hammer et al., 2006). Population centroids with $95 \%$ ellipses derived from the PCA scatter diagram were

Table 1. The probabilities (P) and means of morphometrics of wild and cultured Clarias gariepinus from two populations in Ekiti State

\begin{tabular}{|c|c|c|c|}
\hline Traits & $\mathrm{P}$ & $\begin{array}{l}\text { Wild } \\
\text { mean }\end{array}$ & $\begin{array}{c}\text { Cultured } \\
\text { mean }\end{array}$ \\
\hline Weight $(\mathrm{w})(\mathrm{g})$ & 0.0001 & $250.95 \pm 54.061^{\mathrm{a}}$ & $79.383 \pm 15.689^{\mathrm{b}}$ \\
\hline Total length (TL) $(\mathrm{cm})$ & 0.0001 & $33.337 \pm 2.754^{\mathrm{a}}$ & $21.438 \pm 1.446^{\mathrm{b}}$ \\
\hline Standard length $(\mathrm{SL})(\mathrm{cm})$ & 0.0001 & $30.548 \pm 2.356^{\mathrm{a}}$ & $19.853 \pm 1.272^{\mathrm{b}}$ \\
\hline Dorsal fin length (DFL) $(\mathrm{cm})$ & 0.0001 & $19.026 \pm 1.735^{\mathrm{a}}$ & $12.225 \pm 0.924^{b}$ \\
\hline Anal fin length (AFL) (cm) & 0.0001 & $12.665 \pm 1.126^{\mathrm{a}}$ & $7.975 \pm 0.779^{\mathrm{b}}$ \\
\hline Mouth length $(\mathrm{ML})(\mathrm{cm})$ & 0.0001 & $2.662 \pm 0.540^{\mathrm{a}}$ & $1.951 \pm 0.247^{\mathrm{b}}$ \\
\hline Snout length $(\mathrm{SNL})(\mathrm{cm})$ & 0.0001 & $2.068 \pm 0.239^{\mathrm{a}}$ & $1.156 \pm 0.189^{\mathrm{b}}$ \\
\hline Head length $(\mathrm{HL})(\mathrm{cm})$ & 0.0001 & $8.321 \pm 0.805^{\mathrm{a}}$ & $5.244 \pm 0.406^{b}$ \\
\hline Pre dorsal distance $(\mathrm{PDD})(\mathrm{cm})$ & 0.0001 & $9.787 \pm 0.836^{\mathrm{a}}$ & $6.344 \pm 0.423^{b}$ \\
\hline Pre ventral distance $(\mathrm{PVD})(\mathrm{cm})$ & 0.0001 & $13.698 \pm 1.282^{\mathrm{a}}$ & $8.890 \pm 0.599^{\mathrm{b}}$ \\
\hline Pre pectoral distance $(\mathrm{PPD})(\mathrm{cm})$ & 0.0001 & $6.515 \pm 0.624^{\mathrm{a}}$ & $4.365 \pm 0.439^{\mathrm{b}}$ \\
\hline Pre anal distance $(\mathrm{PAD})(\mathrm{cm})$ & 0.0001 & $17.312 \pm 3.276^{\mathrm{a}}$ & $11.005 \pm 0.730^{\mathrm{b}}$ \\
\hline Length of occipital fontanelle (OFL) $(\mathrm{cm})$ & 0.4170 & $0.618 \pm 0.106^{\mathrm{a}}$ & $0.600 \pm 0.104^{\mathrm{a}}$ \\
\hline Width of occipital fontanelle $(\mathrm{OFW})(\mathrm{cm})$ & 0.0154 & $0.363 \pm 0.070^{\mathrm{a}}$ & $0.326 \pm 0.075^{\mathrm{b}}$ \\
\hline Distance between snout and occipital process (DSO) $(\mathrm{cm})$ & 0.0001 & $6.118 \pm 0.569^{\mathrm{a}}$ & $3.803 \pm 0.330^{\mathrm{b}}$ \\
\hline Body depth (BD) (cm) & 0.0001 & $5.552 \pm 0.732^{\mathrm{a}}$ & $4.390 \pm 0.537^{\mathrm{b}}$ \\
\hline Head width $(\mathrm{HW})(\mathrm{cm})$ & 0.0001 & $5.437 \pm 0.639^{\mathrm{a}}$ & $3.496 \pm 0.437^{\mathrm{b}}$ \\
\hline Inter orbital distance (ID) $(\mathrm{cm})$ & 0.0001 & $3.425 \pm 0.339^{\mathrm{a}}$ & $2.080 \pm 0.193^{\mathrm{b}}$ \\
\hline Distance between dorsal and caudal fin (DDCF) $(\mathrm{cm})$ & 0.0001 & $1.554 \pm 0.377^{\mathrm{a}}$ & $1.016 \pm 0.326^{\mathrm{b}}$ \\
\hline Distance between occipital process and dorsal fin (DODF) $(\mathrm{cm})$ & 0.0001 & $1.441 \pm 0.279^{\mathrm{a}}$ & $1.113 \pm 0.232^{\mathrm{b}}$ \\
\hline Caudal peduncle depth (CPD) $(\mathrm{cm})$ & 0.0001 & $2.444 \pm 0.336^{a}$ & $1.378 \pm 0.152^{\mathrm{b}}$ \\
\hline Pectoral fin length right $(\mathrm{PFL})(\mathrm{cm})$ & 0.0001 & $3.206 \pm 0.484^{\mathrm{a}}$ & $1.831 \pm 0.258^{\mathrm{b}}$ \\
\hline Eye diameter right $(\mathrm{ED})(\mathrm{cm})$ & 0.0001 & $0.642 \pm 0.095^{\mathrm{a}}$ & $0.429 \pm 0.225^{\mathrm{b}}$ \\
\hline Spine length $(\mathrm{SPL})(\mathrm{cm})$ & 0.0001 & $1.987 \pm 0.375^{\mathrm{a}}$ & $1.207 \pm 4.301^{\mathrm{b}}$ \\
\hline Pectoral fin length left $(\mathrm{PFL})(\mathrm{cm})$ & 0.0459 & $3.156 \pm 0.556^{a}$ & $1.791 \pm 0.314^{\mathrm{b}}$ \\
\hline Eye diameter left $(\mathrm{ED})(\mathrm{cm})$ & 0.0001 & $0.635 \pm 0.111^{\mathrm{a}}$ & $0.541 \pm 0.329^{b}$ \\
\hline Spine length left $(\mathrm{SPL})(\mathrm{cm})$ & 0.0001 & $1.941 \pm 0.330^{\mathrm{a}}$ & $1.282 \pm 0.448^{\mathrm{b}}$ \\
\hline
\end{tabular}


used to visualize the relationships among populations (Turan $e t$ al., 2005). PCA loadings were used to show the traits with the highest variation within the population and cluster analyses were used to show the relationship in their clustering patterns (Majolagbe et al., 2012) using the unweighted Pair Group Method with arithmetic mean for phenogram or dendrogram grouping as reported by Sneath and Sokal (1973).

\section{Results}

The ratio of males to females in the two populations did not conform to $1: 1$ ratio. For the wild population, it was $4: 1$ and for the cultured population, it was 3:1. Table 1 shows the result of the morphometric measurements of $C$. gariepinus in the two populations. The means of morphometric traits were significantly different from each other, except the length of occipital fontanelle (OFL), for which there was no significant difference $(\mathrm{P}>0.05)$. Mean \pm standard deviation of wild population was $0.618 \pm 0.106$, whereas mean \pm standard deviation of cultured population was $0.600 \pm 0.104$.

The differences in the meristic traits of $C$. gariepinus from the two populations are shown in Table 2. There were significant differences $(\mathrm{P}<0.05)$ in the means of the meristic traits, except in the DFR, VC, $\mathrm{nG}$ (right), GA (right), $\mathrm{nS}$ (right), nB (right), nG (left), GA (left), nB (left) for which there were no significant differences between the two populations $(\mathrm{P}>0.05)$.

Multivariate analysis of the morphometric traits of Clarias gariepinus in wild and cultured populations

The two clusters representing wild and cultured populations intersected almost completely in the PCA scatter diagram (Fig. 1). Fig. 2 shows the PCA loadings of the morphometrics of wild and cultured populations of $C$. gariepinus indicating anal fin length (AFL) (with loading 0.8087 ) as the character most responsible for the variation between the two populations. In Fig. 3, the similarity coefficient of the morphometrics of the wild and cultured populations of C. gariepinus was $92.4 \%$.
PCA analysis of the morphometric traits of wild and cultured male and fermale Clarias gariepinus

In Fig. 4, all the clusters of male and female members of the two populations intersected almost completely. Only two cultured catfish ( 1 male, 1 female) were not included in the clusters of the wild catfish.

Cluster analysis of the morphometric traits of wild male and female Clarias gariepinus

In Fig. 5, the similarity coefficient of the morphometrics of wild male and female $C$. gariepinus was $92.6 \%$, while the similarity coefficient of the morphometrics of cultured male and female Clarias gariepinus was 95.2\% in Fig. 6.

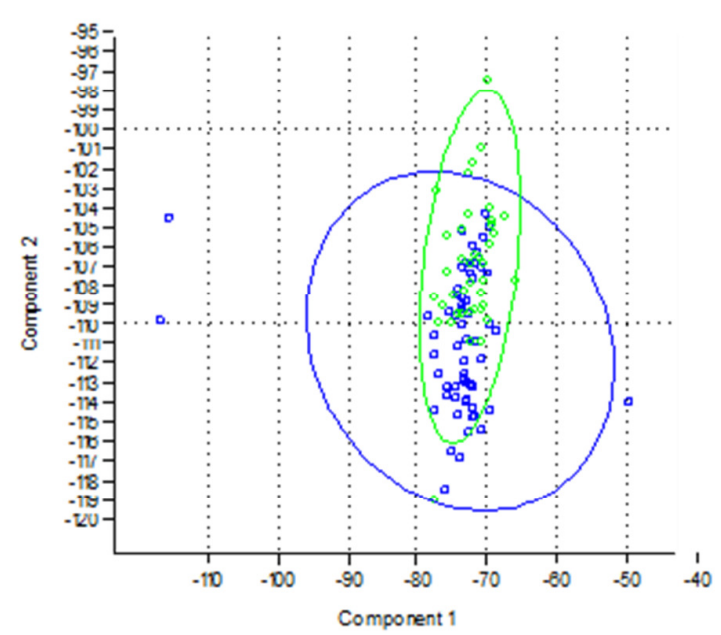

Fig. 1. PCA scatter diagram (95\% ellipses) of morphometrics of wild and cultured samples of Clarias gariepinus showing overlap of traits

*Blue color indicates wild samples, while green color indicates cultured samples

Table 2. The probabilities and means of meristics of wild and cultured Clarias gariepinus from two populations in Ekiti State

\begin{tabular}{|c|c|c|c|}
\hline Traits & $\mathrm{P}$ & $\begin{array}{l}\text { Wild } \\
\text { mean }\end{array}$ & $\begin{array}{c}\text { Cultured } \\
\text { mean }\end{array}$ \\
\hline Dorsal fin ray(DFR) & 0.0630 & $65.800 \pm 3.583^{a}$ & $63.975 \pm 6.129^{\mathrm{a}}$ \\
\hline Anal fin ray (AFR) & 0.0009 & $50.500 \pm 2.361^{a}$ & $48.175 \pm 4.414^{b}$ \\
\hline Number of vertebrae column(VC) & 0.0539 & $56.267 \pm 6.507^{a}$ & $52.397 \pm 4.779^{a}$ \\
\hline Number of Gills right ( $\mathrm{nG}$ ) & & $4^{a}$ & $4^{\mathrm{a}}$ \\
\hline Number of Gill rakers right (GR) & 0.0001 & $50.500 \pm 9.329^{a}$ & $33.025 \pm 3.278^{b}$ \\
\hline Number of Gill filament right (GF) & 0.0001 & $90.050 \pm 8.558^{a}$ & $60.450 \pm 6.571^{b}$ \\
\hline Number of Gill arch right (GA) & & $1^{\mathrm{a}}$ & $1^{\mathrm{a}}$ \\
\hline Number of Spine right $(\mathrm{nS})$ & 0.0739 & $1^{\mathrm{a}}$ & $1.053 \pm 0.226^{a}$ \\
\hline Pectoral fin ray right (PFR) & 0.0001 & $7.933 \pm 1.006^{\mathrm{a}}$ & $6.297 \pm 2.247^{b}$ \\
\hline Pelvic fin ray right (PVFR) & 0.0219 & $5.650 \pm 0.840^{\mathrm{a}}$ & $5.086 \pm 1.522^{b}$ \\
\hline Number of barbells right $(\mathrm{nB})$ & & $4^{\mathrm{a}}$ & $4^{\mathrm{a}}$ \\
\hline Number of Gills left (nG) & & $4^{\mathrm{a}}$ & $4^{\mathrm{a}}$ \\
\hline Number of Gill rakers left (GR) & 0.0001 & $50.283 \pm 9.352^{a}$ & $33.025 \pm 3.278^{\mathrm{b}}$ \\
\hline Number of Gill filament left (GF) & 0.0001 & $90.050 \pm 8.556^{a}$ & $60.450 \pm 6.571^{b}$ \\
\hline Number of Gill arch left (GA) & & $1^{\mathrm{a}}$ & $1^{a}$ \\
\hline Number of Spine left (nS) & 0.0001 & $1^{\mathrm{a}}$ & $1.121 \pm 0.415^{b}$ \\
\hline Pectoral fin ray left (PFR) & 0.0001 & $7.932 \pm 1.449^{\mathrm{a}}$ & $6.118 \pm 2.826^{b}$ \\
\hline Pelvic fin ray left (PVFR) & 0.0054 & $5.633 \pm 0.822^{\mathrm{a}}$ & $4.973 \pm 0.404^{b}$ \\
\hline Number of barbells left (nB) & & $4^{a}$ & $4^{\mathrm{a}}$ \\
\hline
\end{tabular}

${ }^{*}( \pm$ s.d $)=$ Standard deviations. Means in the same row with different superscripts differ significantly $(\mathrm{P}<0.05)$ 


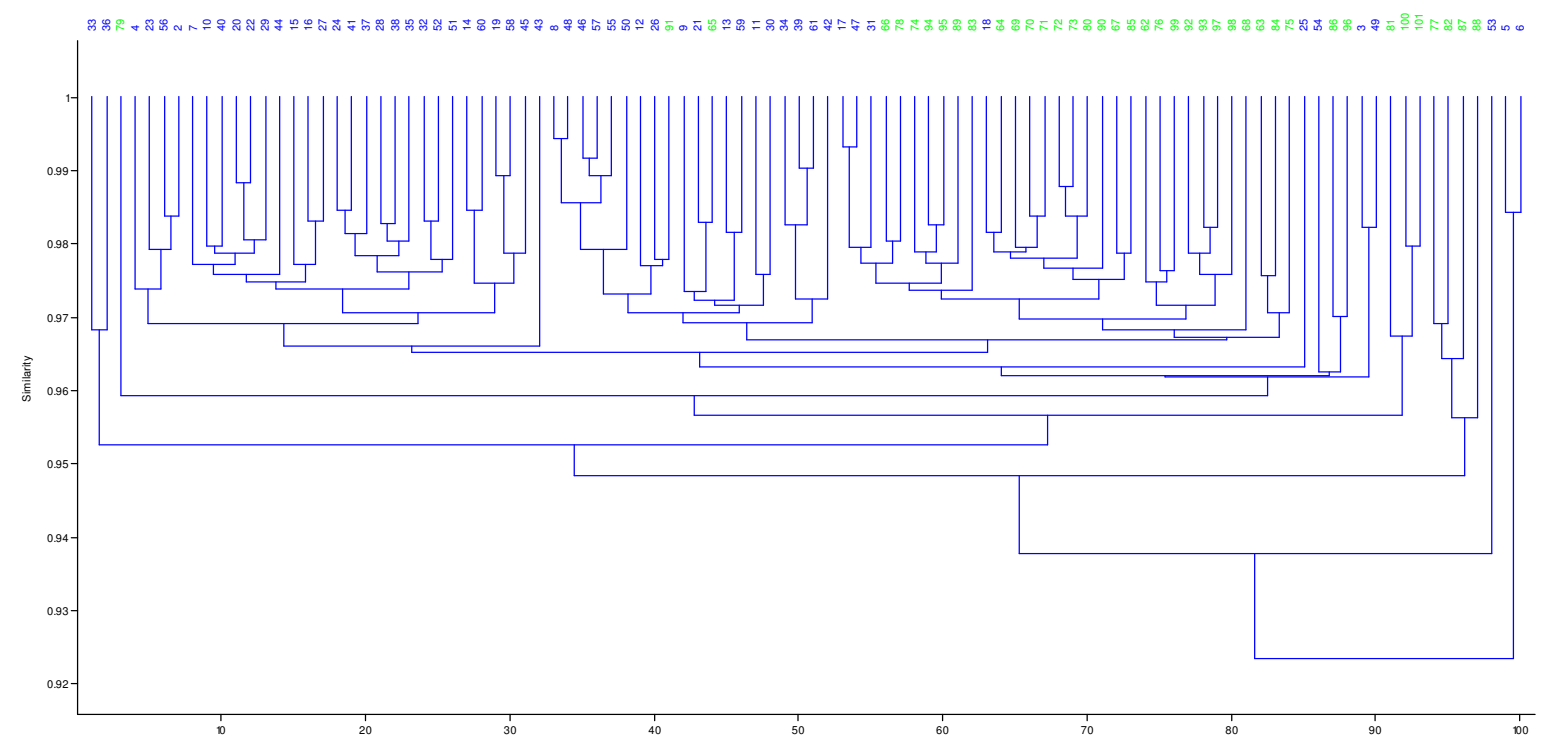

Fig. 3. Dendrogram showing similarity coefficient (92.4\%) of the morphometrics of wild and cultured samples of Clarias gariepinus employing the Bray-Curtis's clustering algorithm

${ }^{*}$ Blue color indicates wild samples, while green color indicates cultured samples

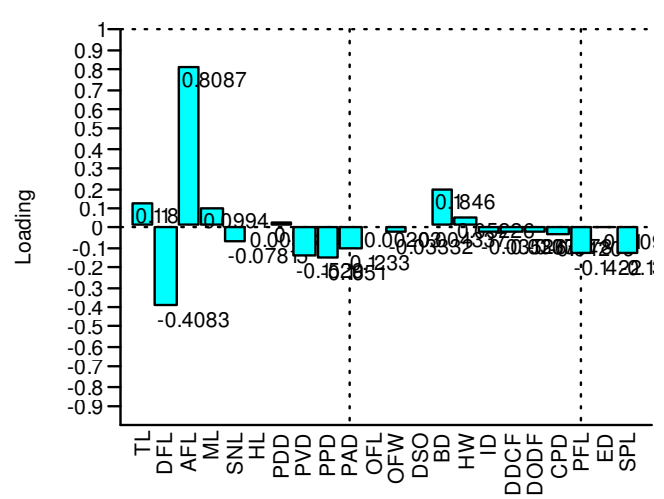

Fig. 2. PCA loadings of morphometrics of wild and cultured samples of Clarias gariepinus

Multivariate analysis of the meristic traits of Clarias gariepinus in wild and cultured populations

Fig. 7 shows the PCA scatter diagram for the meristics of right side of the body of C. gariepinus from the two populations. Here, the two populations are separated. Number of gill filament (GF) (with loading 0.8365 ) was the trait most responsible for variation between the two populations (Fig. 8). As seen in Fig. 9, the similarity coefficient for the meristics of the right side of wild and cultured samples of C. gariepinus was $85.8 \%$.

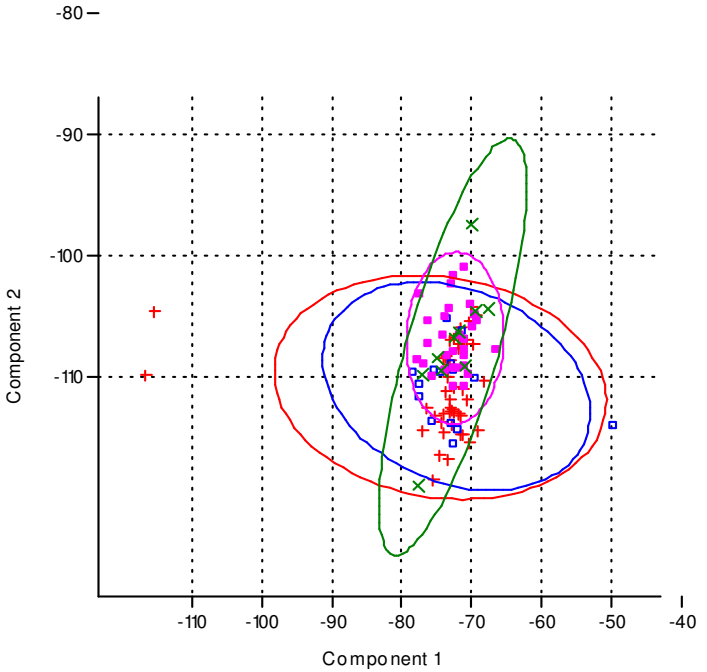

Fig. 4. PCA scatter diagram (95\% ellipses) of the morphometrics of wild and cultured Clarias gariepinus of both genders

${ }^{*}$ Red color indicates wild population (male), blue color indicates wild population (female), pink color indicates cultured population (male) and green color indicates cultured population (female).

PCA of the meristic traits of male and female Clarias gariepinus in wide and cultured populations

In the PCA scatter diagram of the meristics of wild and cultured C. gariepinus of both sexes as shown in Fig. 10, incomplete overlap of traits was observed here. The clusters representing the male and female catfish in each population had common traits. 


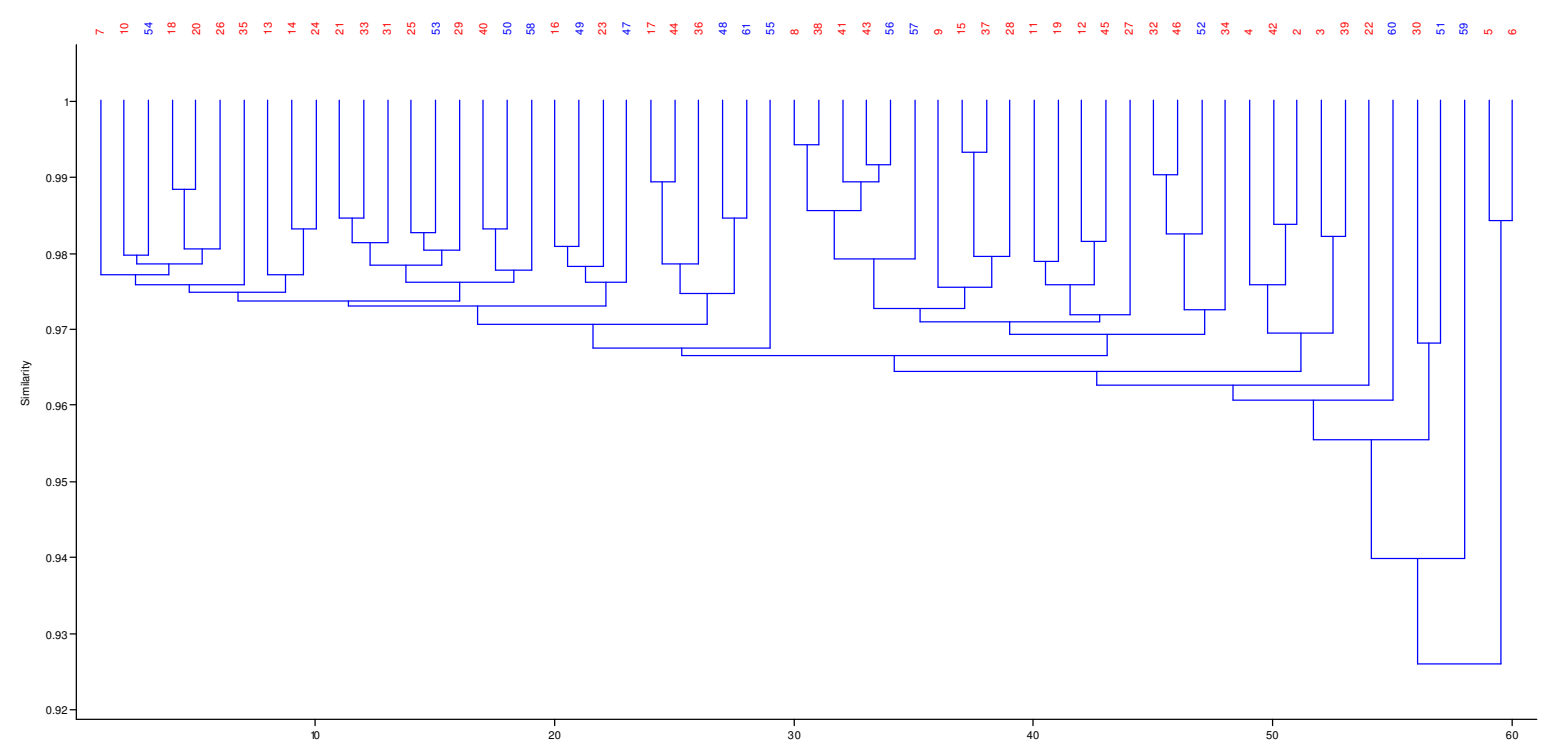

Fig. 5. Dendrogram showing similarity coefficient (92.6\%) of the morphometrics of wild male and female Clarias gariepinus employing the Bray-Curtis's clustering algorithm ${ }^{*}$ Red color indicates male, blue color indicates female

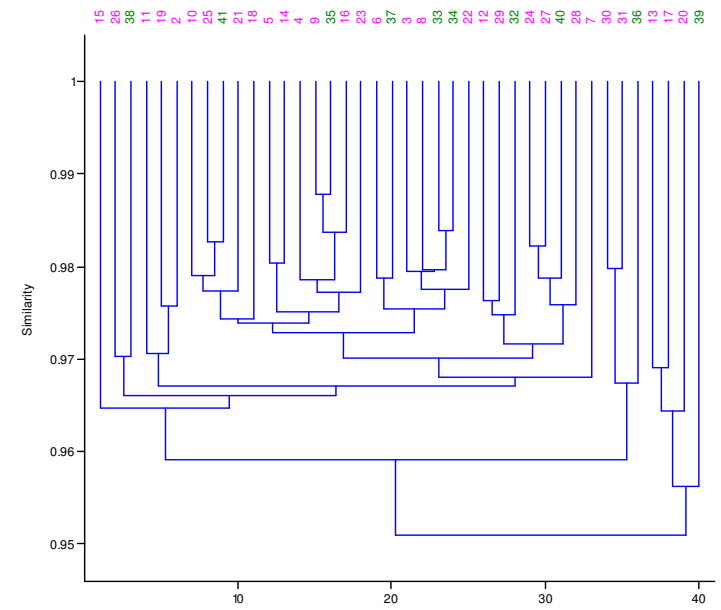

Fig. 6. Dendrogram showing similarity coefficient (95.2\%) of the morphometrics of cultured male and female Clarias gariepinus employing the Bray-Curtis's clustering algorithm *Pink color indicates male, green color indicates female

Cluster analyses of the meristic traits of each of the populations

The similarity coefficient of meristic traits of the right side of wild population was $89.2 \%$, while that of the cultured population was $90.2 \%$ (Figs. 11 and 12).

\section{Discussion}

The significant differences observed in the means of all the morphometric traits, except in the length of occipital fontanelle (OFL), and the significant differences in the means of the meristic traits, except in the DFR, VC, nG (right), GA (right),

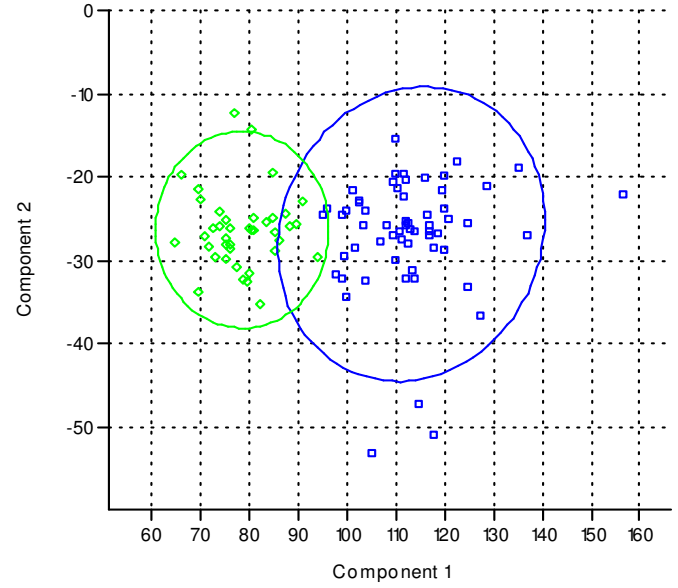

Fig. 7. PCA scatter diagram (95\% ellipses) of the meristics of right side of the body of Clarias gariepinus from the two populations

*Blue color indicates wild population and green color indicates cultured population

$\mathrm{nS}$ (right), nB (right), nG, GA (left), nB (left), between the two populations revealed the existence of heterogeneity between the two populations. Usually, meristic traits are the same in the same species except if some conditions like environmental pollution have changed the phenotype; congenital deformities may also have arisen due to errors during cell divisions. Allendorf et al. (1987) stated that meristic traits are fixed early in development, while morphometric traits are more susceptible to the environment. 


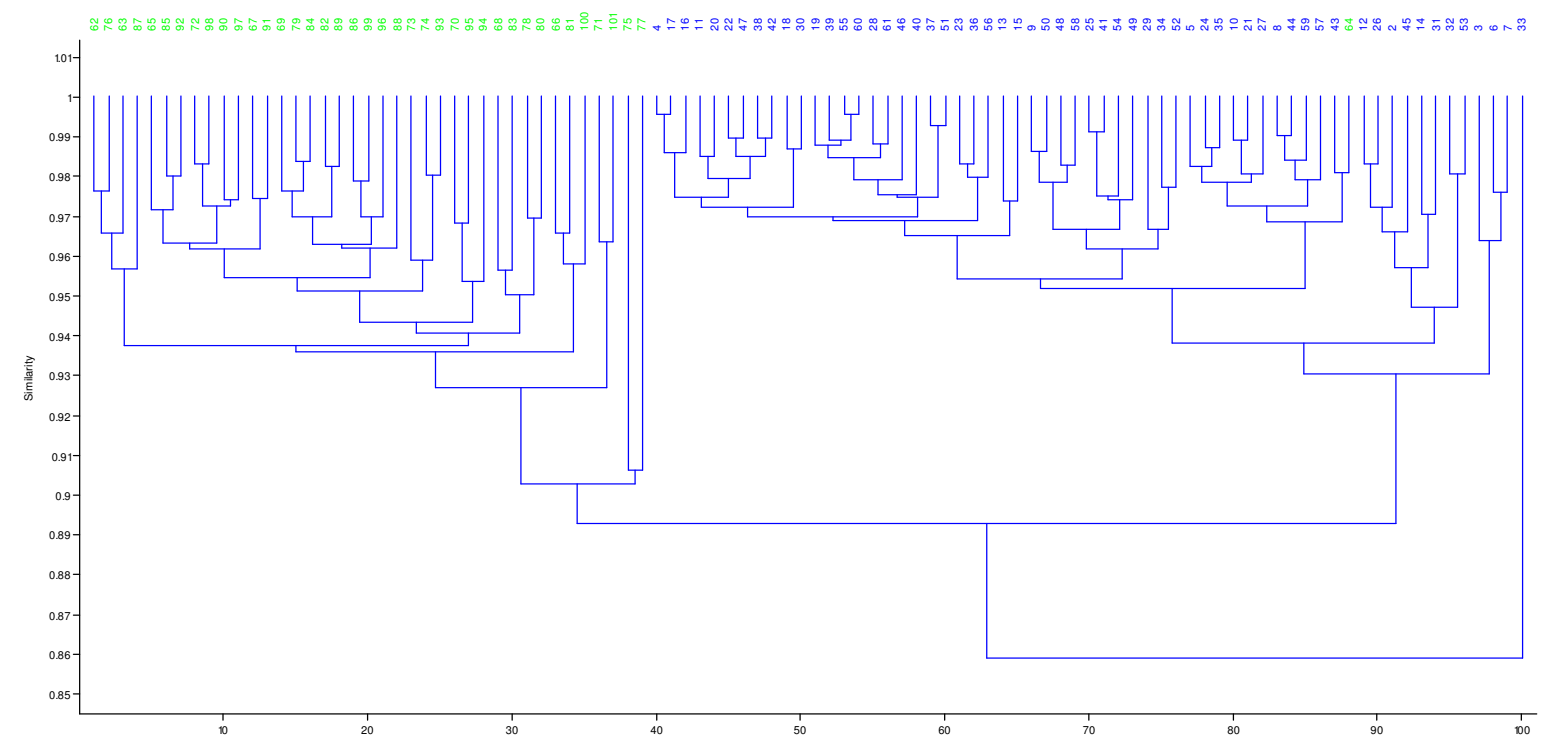

Fig. 9. Dendrogram showing similarity coefficient (85.8\%) of the meristics of right side of wild and cultured samples of Clarias gariepinus employing the Bray-Curtis's clustering algorithm

${ }^{*}$ Blue color indicates wild population and green color indicates cultured population

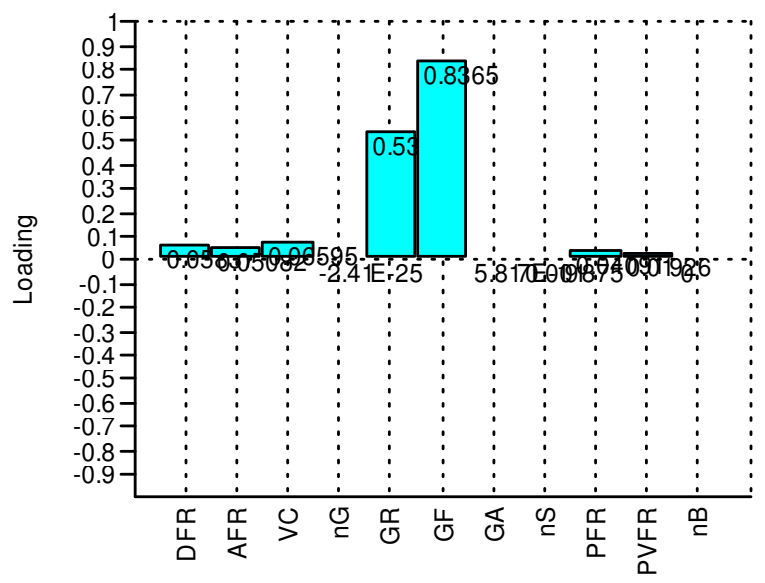

Fig. 8. PCA loadings for the meristics of the right side of wide and cultured Clarias gariepinu

Therefore, some conditions may have caused the alteration in the meristic traits of the studied catfish. This is evidenced in the aberrations observed during the study among the cultured stocks. According to Klug et al. (2011), mutations can occur spontaneously as a result of natural and chemical processes, or they can be induced by external factors, such as chemicals or radiation, although it has been reported that fish generally show greater variance in morphological traits, both within the same species, different species and between populations, than do any other vertebrates. This is due to differences in feeding environments, prey types, food availability, and other features (Dunham et al., 1979; Allendorf and Phelps, 1988; Thompson, 1991; Wimberger, 1992).

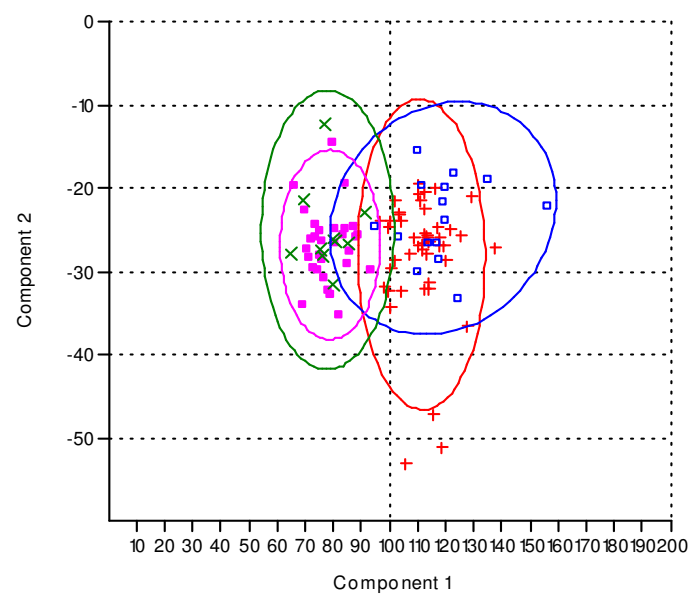

Fig. 10. PCA scatter diagram (using 95\% ellipses) of the meristics of the right side of wild and cultured Clarias gariepinus of both sexes, showing incomplete overlap of traits ${ }^{*}$ Red color indicates wild population (male), blue color indicates wild population (female), pink color indicates cultured population (male) and green color indicates cultured population (female).

Fagbuaro et al. (2015) reported similarities in the morphometric composition of Clarias gariepinus collected from a fish pond in Emure- Ekiti (controlled population) and Ogbese River (uncontrolled population); however, this does not conform to the data obtained in the present study. Even more, for the meristic characters reported by Fagbuaro et al. (2015), the means for the dorsal fin ray, anal fin ray, pectoral fin 


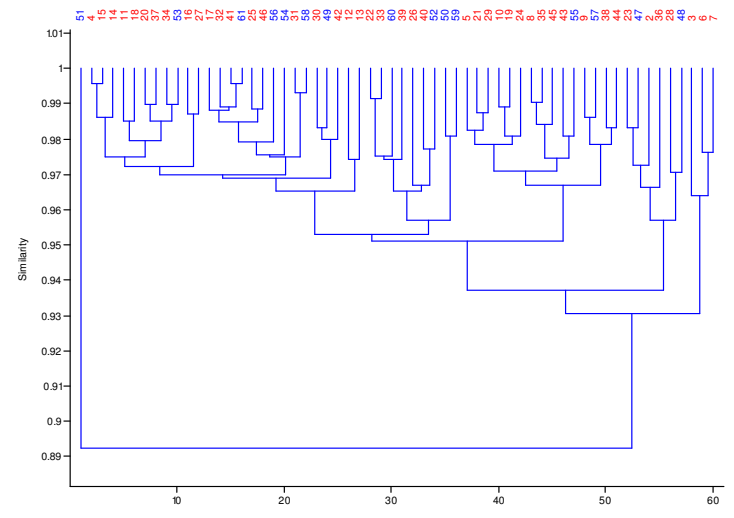

Fig. 11. Dendrogram showing similarity coefficient (89.2\%) of the meristics of right side of wild Clarias gariepinus employing the Bray-Curtis's clustering algorithm

${ }^{*}$ Red color indicates male, blue color indicates female

ray and pelvic fin ray were 66.0 and 64.0, 51.0 and 48.0, 8.0 and $8.0,6.0$ and 6.0 for cultured and wild populations respectively. Whereas the means obtained from the present study were 64.0 and 65.8, 48.2 and 50.5, 6.3 and 7.9, 5.1 and 5.7 for cultured and wild populations respectively, thus different values were obtained. Eyo and Mgbenka (1992) found that specific differences in meristic counts were exhibited in both the anal fin ray and the vertebral count in the Clariids of Anambra River, Nigeria. There was a close numerical relationship between the number of anal fin rays and the number of vertebrae, but this was not similar to the data obtained in the present experiment.

In the hereby study, there were shape and color differences between the two fish populations; also, loss of eye, spine, pectoral fin ray and pelvic fin ray were observed. It was recorded from Iyin pond that six (6) C. gariepinus did not have pectoral fin ray (PFR) on the left side and four (4) did not have pectoral fin ray (PFR) on the right side. Two (2) did not have pelvic fin ray (PVFR) on the left side and six (6) did not have pelvic fin ray (PVFR) on the right. From Ero dam population, only one (1) C. gariepinus did not have pectoral fin ray (PFR). This may confirm the statement by Parish and Sharman (1958) saying that difference in the morphological character of a species from different regions can result from differences in genotype, environmental factors operating on one genotype, or both of these acting together. The presence of loss of some body parts was higher in the cultured population than in the wild population. This may be due to mutation and errors during recombination. El-Serafy et al. (2007) reported that hybridization through extensive inbreeding was a possible cause of morphological variation. It is an established fact that most cultured African fish species have been genetically polluted (Olufeagba et al., 2002), hence this could have led to the remarkable phenotypic changes in this study.

For the morphometrics of wild and cultured populations of C. gariepinus, the PCA loadings indicated anal fin length as the character most responsible for variation between the two populations, while the number of gill filament was the trait most responsible for variation between the two populations for

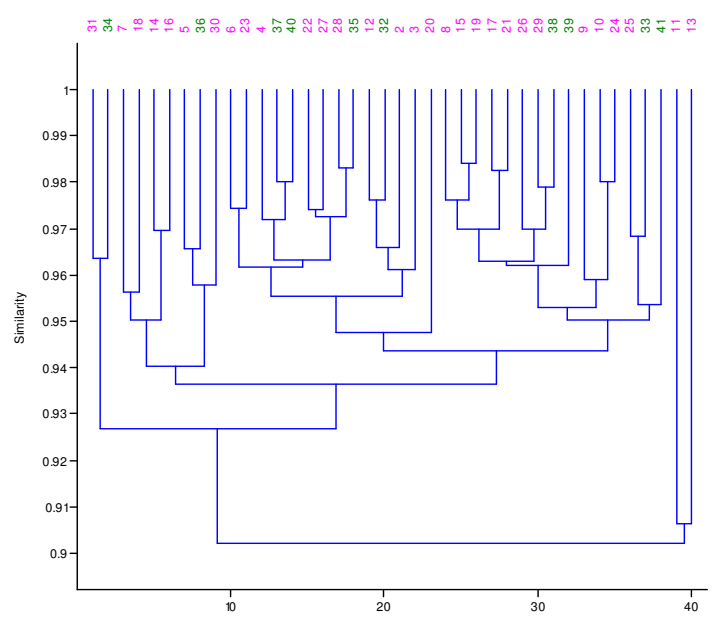

Fig. 12. Dendrogram showing similarity coefficient (90.2\%) of the meristics of right side of cultured Clarias gariepinus employing the Bray-Curtis's clustering algorithm *Pink color indicates male, green color indicates female

the meristic traits. However, Oladimeji et al. (2015) found that lower jaw width was the character most responsible for variation among the three wide populations of $T$. zillii studied.

The PCA scatter diagram in Fig. 4 illustrated incomplete homogeneity of characters between the wild and cultured populations; however, Solomon et al. (2015) reported that analyses of morphometric characters revealed abundant variation among different populations. From cluster analysis, higher morphometric differences were observed between the wild male and female $C$. gariepinus than in the cultured male and female population, though the numerical values were close. This suggests that the two populations are same species despite the variations between them. Though, further genetic tests can be done to confirm this idea.

It has been established that meristic characters are independent of fish size; hence, they should not change during growth (Strauss, 1985). However, in the current study the incomplete overlap of traits observed in the PCA scatter diagram of the meristics of right side of wild and cultured $C$. gariepinus of both genders showed that the meristic characters were different. This may also suggest that the two populations were different, though they still exhibited similarity of traits. This is in contrast with the report by Solomon et al. (2015) where the meristic counts on $C$. gariepinus overlapped so widely among the sexes from different culture environments, so that the populations could not have been discriminated by sex or by culture environment. Oladimeji et al. (2015) also reported that the PCA diagram of the meristic counts done on Tilapia zillii showed no specific pattern of differentiation among three natural populations.

There was lower similarity coefficients of the morphometrics and meristics in male and female of right side of wild $C$. gariepinus compared to that of the cultured population. This suggested that there are higher variations in the wild population than in the cultured population and may also suggest higher sex related variation in the wild than in cultured population. This is almost in line with the report by 
435

Turan et al. (2005) that noted there were negligible sex variations in C.gariepinus from six wild populations in Turkey. Solomon et al. (2015) also reported phenotypic plasticity of $C$. gariepinus to be high within sexes and for different culture environments.

\section{Conclusions}

The present analysis suggests morphological diversity between the two populations studied. Significant difference in meristics of the two populations could be related to some abnormalities (which are loss of eye, spine, pectoral fin ray and pelvic fin ray) observed in the cultured fish samples, that may have been formed during embryogenesis. However, only one wild Clarias gariepinus lacked pectoral fin ray in the hereby study. Therefore, the loss of some anatomical features, which is frequent in the cultured population than in the wild population, may be a result of chromosomal aberrations and mutations. Also, inbreeding could have led to the observed phenotype. Hence, there should also be further genetic tests on the fish specimens to detect the chromosomal and molecular differences between these populations, which would be very helpful to confirm the detected phenotypic differentiation. Also, the wild population can be sampled and bred to examine their growth performances, if they can be used for commercial purposes.

\section{Acknowledgements}

The authors thank Dr. E.O. Idowu of the Department of Zoology, EKSU, for the identification of the specimens and Mrs. Tofunmi Oladimeji of the Department of Zoology, OAU, for her assistance in the analyses.

\section{References}

Adewolu MA, Ogunsanmi AO, Yunusa A (2008). Studies on growth performance and feed utilization of two Clariid catfish and their hybrid reared under different culture systems. European Journal of Scientific Research 23(2):252-260.

Adewolu MA, Adeoti AJ (2010). Effect of mixed feeding schedules with varying dietary crude protein levels on the growth and feed utilization of Clarias gariepinus (Burchell, 1822) fingerlings. Journal of Fisheries and Aquatic Sciences 5:304-310.

Agnew DJ (1988). Evidence for the existence of two populations of Irish Sea cod (Gadus morhua L.) from consideration of growth rates - ICES Committee Meeting Papers 1988/G 65.

Allendorf FW, Ryman N, Utter FM (1987). Genetics and fishery management. In: Ryman N, Utter F (Eds). Population genetics and fishery management. Washington Sea Grant Program. University of Washington, Seattle pp 1-9.

AllendorfFW, Phelps SR (1988). Loss of genetic variation in hatchery stock of cutthroat trout. Transactions of the American Fisheries Society 109(5):537-543.

Atanda AN (2007). Freshwater fish seed resources in Nigeria. Bondad-REanteso MG (Ed). Assessment of freshwater fish seed resources for sustainable aquaculture. FAO Fisheries Technical Paper No. 501, Rome, FAO 628P:361-380.
Avsar D (1994). A stock differentiation study of the sprat (Sprattus sprattus phalericus Risso) off the Southern Coast of the Black sea. Fisheries Research 19(3):363-378.

Bronte CR, Fleischer GW, Maistrenko SG, Pronin NM (1999). Stock structure of Lake Baikal omul as determined by whole body morphology. Journal of Fish Biology 54(4):787-798.

Creech S (1992). A multivariate morphometric investigation of Atherina boyeri Risso, 1810 and A. presbyter Cuvier, 1829 (Teleostei: Atherinidae): morphometric evidence in support of the two species. Journal of Fish Biology 41(3):341-353.

Dunham AE, Smith GR, Taylor JN (1979). Evidence for ecological character displacement in western American catostomid fishes. Evolution 33:877-896.

El-Serafy SS, Abdel-Hameid N-AH, Awwad MH, Azab MS (2007). DNA ribopr .inting analysis of Tilapia species and their hybrids using restriction fragment length polymorphisms of the small subunit ribosomal DNA. Aquaculture Research 38(3):295-303.

Eyo JE, Mgbenka BO (1992). Aspect of the biology of Clarias gariepinus in Anambra river basin I: Oocyte diameter fecundity and sex ratio. Journal of Agricultural Science and Technology 2(I):47-51.

Fagbuaro O, Oso JA, Olurotimi MB Akinyemi O (2015). Morphometric and meristic characteristics of Clarias gariepinus from controlled and uncontrolled population from South Western Nigeria. Journal of agriculture and ecology research international. Article no: JAERI.2015.005.

Ferguson MM, Danzmann RG (1998). Role of genetic markers in fisheries and aquaculture: useful tools or stamp collecting? Canadian Journal of Fisheries and Aquatic Science 55:1553-1563.

Hammer Øyvind, Harper DAT, Ryan PD (2006). PAST Paleontological Statistics version 1.58. Retrieved 2016 February 22 from http://folk.Uio.no/ohammer/past.

Hockaday S, Beddow TA, Stone M, Hancock P, Ross LG (2000). Using truss networks to estimate the biomass of Oreochromis niloticus and to investigate shape characters. Journal of Fish Biology 57:981-1000.

Jordi L, Jordi S, Torres GJ (2000). Removing allometric effects of body size in morphological analysis. Journal of Theoretical Biology 205:85-93.

Klug WS, Cummings MR, Spencer CA, Palladino MA (2011). Concept of genetics. 10th ed. Pearson Benjamin Cummings, California.

Majolagbe FA, Awodiran MO, Awopetu JI (2012). Electrophoretic studies of Clarias gariepinus (Burchell 1822) and Heterobranchus bidorsallis (Geoffroy Saint- Hilaire 1809) and their hybrids. Ife Journal of Science 14(1):167-176.

Mamuris Z, Apostolidis AP, Panagiotaki P, Theodorou AJ, Triantaphllidis C (1998). Morphological variation between red mullet populations in Greece. Journal of Fish Biology 52:107-117.

Oladimeji TE, Awodiran MO, Komolafe OO (2015). Genetic differentiation studies among natural populations of Tilapia zillii. Notulae Scientia Biologicae 7(4):423-429. 
Olufeagba SO, Aluko PO, Eyo AA (2002). Dietary protein requirements of triploid Heterobranchus. Journal of Aquatic Science 17:1-4.

Parish BB, Sharman DP (1958). Some remark on method used in herring 'racial' investigations, with special reference to otolith studies - Rapports et Process-verbaux des Reunions. Conseil International pour l'Exploration de la Mer 143:66-80.

Reist JD (1985). An empirical evaluation of several univariate methods that adjust for size variation in morphometric data. Canadian Journal of Zoology 63:1429-1439.

Solomon SG, Okomoda VT, Ogbenyikwu AI (2015). Intraspecific morphological variation between cultured and wild Clarias gariepinus (Burchell) (Clariidae, Siluriformes) - Archives of Polish Fisheries 23:53-61.

Sneath PH, Sokal RR (1973). The principle and practice of numerical classification. Numerical Taxonomy: WH Freeman and Co. San Francisco, USA.

Strauss RE (1985). Evolutionary allometry and variation in body form in the South American catfish genus Corydoras (Callichthydae). Systematic Biology 34:381-396.

Swain DP, Foote CJ (1999). Stocks and chameleons the use of phenotypic variation in stock identification. Fisheries Research 43:113-128.
Thompson JD (1991). Phenotypic plasticity as a component of evolutionary change. Trends in Ecology and Evolution 6:246-249.

Turan C (2004). Stock Identification of Mediterranean horse mackerel (Trachurus mediterraneus) using morphometric and meristic characters. ICES Journal of Marine Science 61:774-781.

Turan C, Erguden D, Turan F, Gurlek M (2004). Genetic and morphologic structure of Liza abu (Heckel, 1843) populations from the Rivers Orontes, Euphrates and Tigris. Turkish Journal of Veterinary and Animal Science 28:729-734.

Turan C, Yalcin S, Turan F, Okur E, Akyurt I (2005). Morphometric comparisons of African catfish, Clarias gariepinus, populations in Turkey. Folia Zoologica 54:165-172.

Wimberger PH (1992). Plasticity of fish body shape, the effects of diet, development, family and age in two species of Geophagus (Pisces: Cichlidae). Biological Journal of the Linnean Society 45:197-218. 